\title{
PENANAMAN NILAI-NILAI NASIONALISME DALAM PEMBELAJARAN PKn di Kelas VIII MTs 6 ACEH BESAR
}

\author{
MARDHIAH \\ Guru PKn pada MTsN 6 Aceh Besar \\ e-mail : mardhiah9@gmail.com
}

\begin{abstract}
ABSTRAK
Tujuan penelitian: 1) Penanaman nilai-nilai nasionalisme pada kegiatan pendahuluan dalam pembelajaran PKn 2) Penanaman nilai-nilai nasionalisme pada kegiatan inti dalam pembelajaran PKn 3) Penanaman nilai-nilai nasionalisme pada kegiatan penutup dalam pembelajaran PKn di kelas VIII MTs Negeri 6 Aceh Besar. Jenis penelitian kualitatif dengan pendekatan kualitatif deskriptif. Teknik pengumpulan data menggunakan dokumentasi, wawancara dan observasi. Analisis data dilakukan dengan mengorganisasikan data, menjabarkannya ke dalam unit-unit, melakukan sintesa, menyusun ke dalam pola, memilih mana yang penting dan yang akan dipelajari, dan membuat kesimpulan yang dapat diceritakan kepada orang lain. Ada tiga tahapan dalam analisis data yaitu reduksi data, penyajian data, dan verifikasi. Hasil penelitian: 1) Penanaman nilai-nilai nasionalisme pada kegiatan pendahuluan dalam pembelajaran PKn di kelas VIII MTs Negeri 6 Aceh Besar dapat dilaksanakan sesuai harapan, hal ini dapat dilakukan dengan apersepsi dengan mempersiapkan sebelum memulai pembelajaran dengan salam dan sapa serta absesnsi dan juga melakukan penjajagan kesiapan belajar siswa dan menginformasikan kompetensi yang akan dicapai; 2) Penanaman nilai-nilai nasionalisme pada kegiatan inti dalam pembelajaran Pkn di kelas VIII MTs Negeri 6 Aceh Besar dapat dilaksanakan sesuai RPP, yaitu dengan eksplorasi, elaborasi dan konfirmasi. Di samping itu penanaman nilai- nilai nasionalisme dilaksanaan melalui berbagai macam strategi yaitu di antaranya: pengintegrasian nilai karakter ke dalam mata pelajaran yang dilaksanakan berdasarkan dengan RPP dengan menyisipkan nilai-nilai dan materi nasionalisme dengan metode, media, dan sumber yang telah dirancang oleh guru, di samping itu melalui kegiatan terprogram dengan melaksanakan kegiatan-kegiatan antara lain; memperingati hari besar nasional, bakti sosial, ekstrakurikuler, menghias kelas dengan tema nasionalisme; 3) Pelaksanaan penanaman nilai karakter pada kegiatan penutup dalam pembelajaran PKn di kelas VIII MTs Negeri 6 Aceh Besar dapat dilaksanakan dengan melakukan penilaian atau refleksi terhadap kegiatan yang sudah dilaksanakan secara konsisten dan terprogram dan merencanakan kegiatan rencana pembelajaran pada pertemuan berikutnya dan kalau perlu melakukan penilaian/tes dan nontes dengan mengacu pada indikator pencapaian nilai-nilai pendidikan karakter, melalui pengamatan guru dalam proses pembelajaran. Penilaian pendidikan nasionalisme dititik beratkan kepada keberhasilan penerapan nilai- nilai dalam sikap dan perilaku peserta didik sesuai dengan nilai nasionalisme yang diterapkan dan diamalkan dalam kehidupan di kelas dan lingkungan sekolah.
\end{abstract}

Kata Kunci : Penanaman, Nilai-nilai Nasionalisme, Pembelajaran PKn.

\section{PENDAHULUAN}

Pendidikan Kewarganegaraan (PKn) menjadi lebih penting ketika melihat kenyataan pada generasi dimana dirasakan adanya berbagai ketimpangan hasil pendidikan dilihat dari perilaku lulusan pendidikan formal saat ini, semisal korupsi, perkembangan seks bebas pada kalangan remaja, narkoba, tawuran, pembunuhan, perampokan oleh para pelajar dan pengangguran sekolah menengah dan atas. Semuanya terasa lebih kuat sejak negara ini dilanda krisis yang berkepanjangan. Dengan melihat kenyataan yang terjadi dalam masyarakat kita saat ini, seperti yang sering kita lihat pada tayangan-tayangan televisi, dan berita-berita yang dimuat di koran/majalah yaitu banyaknya kasus-kasus korupsi, penyalahgunaan obat-obatan, tawuran pelajar, narkoba, miras bahkan terjadinya kasus-kasus pelecehan seksual dan sebagainya. Maka pendidikan PKn diharapkan mampu mengurangi atau bahkan 
membentengi kaum remaja umumnya dan siswa pada khusunya dari perilaku- perilaku yang tidak baik tersebut. Belajar adalah proses perubahan perilaku akibat interaksi individu dengan lingkungan (Sumiati, 2011: 38).

Krisis identitas nasionalisme di negara kita pada era global ini, maka kiranya sudah sangat mendesak bagaimana mewujudkan identitas nasional dan nasionalisme dapat ditanamkan kepada para siswa sebagai warga negara yang dapat dihandalkan bagi bangsa dan negara dimasa depan. Nasionalisme sebagai salah satu paham untuk mengingatkan generasi muda akan kegigihan usaha para pejuang Indonesia dalam merebut kemerdekaan. Jasa para pahlawan memang harus dikenang, namun dikenang saja tidaklah cukup. Karena perjuangan belumlah selesai, para pahlawan bangsa yang telah gugur tentu akan bangga bila perjuangan mereka diteruskan oleh generasi saat ini. Agar dapat meneruskan perjuangan mereka, generasi muda harus meneladani sikap nasionalisme mereka dalam kehidupan sehari-hari.

Penanaman nilai-nilai nasionalisme, salah satunya melalui lembaga pendidikan formal seperti sekolah. Pendidikan Kewarganegaraan merupakan mata pelajaran yang memfokuskan pada pembentukan diri yang beragam dari segi agama, sosial kultur, bahasa, usia dan suku bangsa untuk menjadi warga negara Indonesia yang cerdas, terampil, dan berkarakter yang diamanatkan oleh Pancasila dan UUD 1945. Materi-materi yang terdapat dalam kurikulum Pendidikan Kewarganegaraan diantaranya meliputi: Proklamasi Kemerdekaan dan Konstitusi pertama. Materi tersebut diharapkan mampu memberikan kesadaran nilai-nilai nasionalisme dalam diri siswa untuk mematuhi peraturan yang berlaku.Berdasarkan uraian tersebut dapat disimpulkan bahwa Nasionalisme merupakan salah satu materi Pendidikan Kewarganegaraan, sebagai sarana untuk memberikan penanaman nilainilai nasionalisme sejak dini terhadap siswa-siswi di sekolah. Penanaman nilai-nilai nasionalisme pada siswa di sekolah dimaksudkan untuk menciptakan generasi penerus yang sadar akan rasa nasionalisme. Pendidikan Kewarganegaraan sebagaimana amanat kurikulum harus menghasilkan perubahan perilaku yang lebih matang secara psikologis dan sosiokultural, khususnya sebagai warga negara yang sadar hak dan kewajibannya sebagaimana yang diamanatkan konstitusi.

Tujuan dari penelitian ini: untuk penanamkan nilai-nilai nasionalisme pada kegiatan pendahuluan, kegiatan inti dan kegiatan penutup dalam pembelajaran PKn di kelas VIII MTs Negeri 6 Aceh Besar. Beberapa peneliti terdahulu yang dapat dijadikan acuan, diantaranya adalah: Leung (2009), yang meneliti tentang "Nationalistic Education and Indoctrination (Pendidikan Nasionalis dan Indoktrinasi).Jenis penelitian laporan studi kasus yang berfokus pada pemahaman dan praktik pendidikan nasionalistik terhadap tiga pendidik masyarakat yang memiliki pemahaman tentang pendidikan untuk nasionalisme totaliter di sekolah menengah Hong Kong, dengan menggunakan konsep indoktrinasi. Temuan menunjukkan bahwa karena ketidakmampuan guru memisahkan bangsa dari partai yang berkuasa dan misi kuat mereka untuk mengirimkan citra positif partai kepada murid mereka, mereka cenderung menerapkan strategi pengajaran tertentu, yang dapat menekan kemampuan siswa untuk mencerminkan secara kritis Menurut kriteria indoktrinasi, yaitu hubungan, niat, isi dan metode pengajaran, pendekatan pengajaran mereka cenderung bersifat indoktrinasi, bukan pendidikan. Hal ini tentu saja tidak dapat diterima oleh mereka yang percaya bahwa pendidikan berkaitan dengan pengembangan individu yang berpikiran independen dan kritis. Mudah-mudahan, tulisan ini akan meningkatkan kesadaran akan potensi pendidikan indikatif nasionalistik guru dan menjelaskan perkembangan pendidikan nasional berbasis sekolah yang bertujuan untuk menumbuhkan 'patriot kritis'.

Rewantina (2013), yang meneliti tentang penanaman nilai nasionalisme dan patriotisme untuk mewujudkan pendidikan karakter pada mata pelajaran Pendidikan Kewargenagaraan. Jenis penelitian yang digunakan dalam penelitian ini adalah jenis penelitian kualitatif dengan menggunakan pendekatan kualitatif- deskriptif.Dalam hal ini penelitian menggunakan pendekatan kualitatif yang berasal dari kata-kata yang digali dari informan penelitian, seperti 
dokumen tertulis dan wawancara. Hasil penelitian menyimpulkan bahwa: (1) nasionalisme dan patriotisme tidak hanya ditanamkan pada mata pelajaran dan perangkat pembelajaran. (2) hambatan berupa IPTEK, pemikiran siswa, dan didikan orang tua. (3) upaya berupa kegiatan formal dan non formal yang ada di sekolah.

Setyowati, (2012), yang meneliti tentang Nasionalism Applying in Learning Civic Education as Moral Learning Media ini University, jenis penelitian kepustakaan, data sekunder dikumpulkan dengan mengidentifikasi dokumen, buku, dan jurnal yang relevan. Data diinterpretasikan dan dianalisis secara deskriptif.Penelitian juga memberikan solusi tentang metode penanaman nasionalisme menuju pendidikan tinggi.Hasil ulasannya dapat disimpulkan bahwa pendidikan kewarganegaraan di universitas diwajibkan untuk memperkuat siswa dalam membentuk sikap nasionalisme. Siswa mempelopori masa depan sebuah negara yang harus mereka cintai negara mereka karena ilmu yang diterima harus diterapkan dalam kehidupan sosial mereka.

Nurdin (2015), yang meneliti tentang "The Policies on Civic Education in Developing Nationalism Character in Indonesia" (Kebijakan Pendidikan Kewarganegaraan dalam Mengembangkan Karakter Nasionalis di Indonesia), jenis penelitian deskriptif kualitatif.Hasil penelitian menjelaskan bahwa Pendidikan Kewarganegaraan sebagai pendidikan berbasis nilai yang berasal dari kristalisasi sistem nilai budaya nasional (Pancasila).Pendidikan Kewarganegaraan sebagai mata pelajaran di sekolah dan kursus di institusi pendidikan tinggi dapat mengarahkan siswa untuk memperoleh karakter, pada akhirnya karakter nasional sebagai negara yang bersatu, religius, dan humanis. Dengan fungsi Civic Education sebagai fasilitator pengembangan karakter dan budidaya nasional, diharapkan warga negara Indonesia ke depan dapat mencerminkan warga negara yang mampu mempraktikkan nilai budaya nasional, yaitu Pancasila. Hambatan yang dihadapi dalam pelaksanaan Pendidikan Kewarganegaraan sebagai media pengembangan karakter nasional berada pada komitmen dan kualitas dari mereka yang menerapkannya dan dalam metode pembelajarannya.Fenomena ini menandakan perlunya studi lebih lanjut difokuskan pada implementasi dan evaluasi kebijakan pelaksanaan Pendidikan Kewarganegaraan.

Hoskin, at all (2014), yang meneliti tentang "Civic Competence of Youth in Europe: Measuring Cross National Variation Through the Creation of a Composite Indicator (Kompetensi Kewarganegaraan Pemuda di Eropa: Mengukur Variasi Lintas Nasional Melalui Penciptaan Indikator Komposit). Sebuah artikel yang mengembangkan indikator komposit untuk memantau tingkat kompetensi kewarganegaraan anak muda di Eropa dengan menggunakan studi IEA ICCS

2009.Model pengukuran menggabungkan tradisi di Eropa model kewarganegaraan liberal, sipil republik dan kritis / kosmopolitan.Hasilnya menunjukkan bahwa nilai keadilan sosial dan pengetahuan kewarganegaraan dan keterampilan siswa difasilitasi dalam sistem Nordik yang menggabungkan demokrasi dan kemakmuran ekonomi yang stabil dengan sistem pendidikan berbasis demokrasi di mana para guru memprioritaskan untuk mempromosikan pemikiran kritis otonom dalam pendidikan kewarganegaraan.Sebaliknya, demokrasi jangka menengah dengan tradisi republik sipil, seperti Italia dan Yunani mendapatkan hasil yang lebih positif mengenai nilai kewarganegaraan dan sikap partisipatif.Ini juga terjadi pada beberapa negara komunis baru-baru ini yang mempertahankan gagasan etnik kewarganegaraan. Pada langkah terakhir, kami melanjutkan untuk memperdebatkan bahwa prioritas guru Nordik dalam mengembangkan warga negara yang kritis dan otonom mungkin memfasilitasi kualitas kognisi 14 tahun mengenai kewarganegaraan dan nilai kesetaraan tetapi mungkin bukan pendekatan yang paling bermanfaat untuk meningkatkan sikap atau konsep partisipatif. warga negara yang baik yang mungkin lebih didukung oleh prioritas guru bahasa Italia dalam tanggung jawab kewarganegaraan.

Ismawati (2018), yang melakukan penelitian tentang "Nationalism in Indonesian Literature as Active Learning Material (Nasionalisme dalam Sastra Indonesia sebagai Bahan 
Pembelajaran Aktif).Metode penelitiannya adalah deskriptif inferensial.Karya sastra Indonesia yang diidentifikasikan meliputi karya sastra Balai Pustaka, Pujangga Baru, 1945, 1922, dan kontemporer.Dari hasil penelitian tersebut, dapat disimpulkan bahwa karya sastra Indonesia sejak zaman penjajahan Belanda mulai dari Balai Pustaka sampai karya sastra dewasa ini (kontemporer) mengandung nilai-nilai nasionalisme.Dapat disimpulkan bahwa nilai-nilai nasionalisme dalam karya sastra Indonesia muncul sejak zaman penjajahan Belanda, meski bersifat simbolis.Seiring dengan meningkatnya nilai nasionalisme di kalangan pemuda Indonesia, bahkan dalam karya sastra nilai-nilainya tampak lebih eksplisit, lebih berani, dan tidak hanya simbolis.Hasil ini perlu diajarkan kepada siswa SLA yang menggunakan pembelajaran aktif.Penelitian ini merekomendasikan perlunya bahan ajar nasionalisme yang mudah dicerna untuk mewujudkan karakter nasionalisme di kalangan peserta didik.

Leung, Y.W (2014). Penelitian tentang "Nasionalistic Education and Indostrination", Studi kasus yang berfokus pada pemahaman dan praktik pendidikan nasionalistik terhadap tiga pendidik masyarakat yang pemahamannya mengarah pada pendidikan untuk nasionalisme totaliter di sekolah menengah Hong Kong, dengan menggunakan konsep indoktrinasi.Temuan menunjukkan bahwa karena ketidakmampuan para guru memisahkan bangsa dari partai yang berkuasa dan misi kuat mereka untuk mengirimkan citra positif partai kepada murid mereka, mereka cenderung menerapkan strategi pengajaran tertentu, yang dapat menekan kemampuan siswa.Untuk mencerminkan secara kritis, menurut kriteria indoktrinasi, yaitu hubungan, niat, isi dan metode pengajaran, pendekatan pengajaran mereka cenderung bersifat indoktrinasi, bukan pendidikan.Hal ini tentu saja tidak dapat diterima oleh mereka yang percaya bahwa pendidikan berkaitan dengan pengembangan individu yang berpikiran independen dan kritis.

\section{METODE PENELITIAN}

Jenis penelitian ini adalah penelitian kualitatif. Desain penelitian adalah pengamatan lapangan. Penelitian ini dilaksanakan pada bulan April-September 2019 di Kelas VIII MTs N 6 Aceh Besar. Teknik pengumpulan data dengan menggunakan wawancara, dokumentasi, dan observasi. Dalam penelitian kualitatif wawancara dilakukan secara bebas terkontrol artinya wawancara dilakukan secara bebas sehingga diperoleh data yang luas dan mendalam,tetapi masih memperhatikan unsur terpimpin pada persoalan-persoalan yang diteliti dalam hal inilah pedoman wawancara digunakan.Proses wawancara dalam penelitian ini mengacu pada teori first order understanding dan second order undertsandingyaitu peneliti menginterpretasikan interpretasi dari informan tersebut sehingga menemukan makna baru yang akurat.

Analisis dokumentasi dalam penelitian ini berupa foto-foto, dan naskah- naskah yang terkait dengan penanaman nilai-nilai nasionalisme dalam pembelajaran PKn di Kelas VIII MTs Negeri 6 Aceh Besar Analisis dalam penelitian kualitatif terdiri dari tiga komponen pokok yaitu reduksi data, sajian data, dan penarikan simpulan dengan verifikasinya.

\section{HASIL PENELITIAN DAN PEMBAHASAN}

1. Penanaman Nilai-nilai Nasionalisme pada Kegiatan Pendahuluan dalam pembelajaran

PKn di Kelas VIII MTs Negeri 6 Aceh Besar

Hasil penelitian diketahui bahwa penanaman nilai-nilai nasionalisme pada kegiatan pendahuluan dalam pembelajaran PKn di Kelas VIII MTs Negeri 6 Aceh B esar dapat dilakukan oleh guru yaitu : a) Guru mengkondisikan dan mempersiapkan suasana belajar yang menyenangkan melalui pemberian salam dan sapa kepada siswa dilanjutkan memperhatikan kesiapan fisik dan psikis untuk mengikuti pembelajaran dengan melakukan doa, menanyakan kehadiran siswa, kebersihan dan kerapian, b) Bagi guru kelas VII, menyampaikan ucapan selamat kepada siswa kelas VII yang telah menjadi siswa MTs, c) Guru menyampaikan kompetensi dasar dan indikator pencapaian 
kompetensi yang akan dicapai serta d) Guru menjelaskan materi dan kegiatan pembelajaran yang akan dilakukan siswa.

Perencanaan merupakan menyusun langkah-langkah yang akan dilaksanakan untuk mencapai tujuan yang telah ditentukan. Perencanaan tersebut dapat disusun berdasarkan kebutuhan dalam jangka waktu tertentu sesuai dengan keinginan pembuat perencanaan.Perencanaan yang dibuat harus dapat dilaksanakan dengan mudah dan tepat sasaran. Sesuai uraian di atas, penanaman nilai-nilai nasioanalisme di MTs Negeri 6 Aceh Besar telah direncanakan dengan sedemikian rupa. Berdasarkan hasil penelitian, perencanaan penanaman nilai-nilai nasionalisme di MTs Negeri 6 Aceh Besar dituangkan ke dalam bentuk program kerja dengan tujuan untuk menumbuhkan, memelihara dan mengembangkan kesadaran berbangsa dan bernegara Indonesia, kecintaan terhadap tanah air, keyakinan Pancasila sebagai ideologi, falsafah dan dasar negara, kerelaan berkorban untuk negara, serta kemampuan awal bela negara bagi seluruh warga MTs Negeri 6 Aceh Besar serta dapat menerapkan wawasan kebangsaan itu ke dalam kehidupan seharihari. Hal ini sesuai dengan penelitian yang dilakukan oleh Nurdin (2015) yang meneliti tentang "The Policies on Civic Education in Developing Nationalism Character in Indonesia" (Kebijakan Pendidikan Kewarganegaraan dalam Mengembangkan Karakter Nasionalis di Indonesia), hasil penelitian menjelaskan bahwa Pendidikan Kewarganegaraan sebagai pendidikan berbasis nilai yang berasal dari kristalisasi sistem nilai budaya nasional (Pancasila). Pendidikan Kewarganegaraan sebagai mata pelajaran di sekolah dan kursus di institusi pendidikan tinggi dapat mengarahkan siswa untuk memperoleh karakter, pada akhirnya karakter nasional sebagai negara yang bersatu, religius, dan humanis. Dengan fungsi Civic Education sebagai fasilitator pengembangan karakter dan budidaya nasional, diharapkan warga negara Indonesia ke depan dapat mencerminkan warga negara yang mampu mempraktikkan nilai budaya nasional, yaitu Pancasila. Hambatan yang dihadapi dalam pelaksanaan Pendidikan Kewarganegaraan sebagai media pengembangan karakter nasional berada pada komitmen dan kualitas dari mereka yang menerapkannya dan dalam metode pembelajarannya.Fenomena ini menandakan perlunya studi lebih lanjut difokuskan pada implementasi dan evaluasi kebijakan pelaksanaan Pendidikan Kewarganegaraan.

Hasil penelitian menunjukkan bahwa kegiatan pembiasaan yang dilaksanakan di kelas VIII MTs Negeri 6 Aceh Besar sangat relevan dalam kegiatan pembiasaan itu dapat menanamkan nilai-nilai nasionalisme kepada siswa. Pelaksanaan kegiatan pembiasaan ini dilakukan melalui beberapa pendekatan, strategi, metode dan model melalui kegiatan seperti : upacara Bendera, memperdengarkan lagu-lagu Kebangsaan, mengibarkan Bendera di halaman depan sekolah oleh siswa setiap hari, membudayakan 3S (Senyum, Sapa, Salam), piket kelas, doa awal pelajaran dan akhir pelajaran. Nilai-nilai nasionalisme yang ditanamkan oleh sekolah kepada peserta didik adalah nilai religius, jujur, toleransi, disiplin, kerja keras, kreatif, mandiri, demokratis, rasa ingin tahu, semangat kebangsaan, cinta tanah air, menghargai prestasi, bersahabat/komunikatif, cinta damai, gemar membaca, peduli lingkungan, peduli sosial, tanggung jawab. Tetapi nilai nasionalisme yang utama untuk ditanamkan di MTs Negeri 6 Aceh Besar adalah religius, toleransi, disiplin, cinta tanah air, menghargai prestasi, dan peduli sosial.

2. Penanaman nilai-nilai nasionalisme pada kegiatan inti dalam pembelajaran PKn di MTs Negeri 6 Aceh Besar

Penanaman nilai-nilai nasionalisme pada kegiatan inti dalam pembelajaran PKn di MTs Negeri Ngemplak dapat dijelaskan bahwa pelaksanaan pembelajaran merupakan operasionalisasi dari perencanaan pembelajaran, sehingga tidak lepas dari perencanaan pengajaran/ pembelajaran/pembelajaran yang sudah dibuat. Oleh karenanya dalam pelaksanaannya akan sangat tergantung pada bagaimana perencanaan pengajaran sebagai 
operasionalisasi dari sebuah kurikulum. Penanaman nilai-nilai nasionalisme pada siswa di MTs Negeri 6 Aceh Besar dilaksanakan sesuai dengan perencanaan yang telah disusun oleh sekolah, yaitu dengan waktu 90 menit dimana: 1) Siswa diminta untuk membentuk kelompok (5-2kelompok. @ 2 orang); b) Siswa diminta untuk membaca buku teks untuk kemudian mengamati video/film/gambar sidang BPUPKI dengan penuh rasa syukur pada Tuhan YME dan mencatat hal-hal yang penting atau yang ingin diketahui dari video/film/gambar tersebut. Guru dapat memberi penjelasan singkat tentang gambar, sehingga menumbuhkan rasa ingin tahu siswa berkaitan dengan pembentukan BPUPKI; c) Siswa secara berkelompok mengidentifikasi pertanyaan berkaitan dengan perumusan dan penetapan Pancasila serta sidang BPUPKI dengan penuh rasa tanggung jawab. d) Siswa untuk mencari informasi dengan melakukan kajian dokumen historis dari berbagai sumber (buku, Koran, internet, dsb) tentang proses perumusan dan penetapan Pancasila sebagai dasar Negara dan sidang BPUPKI dengan rasa ingin tahu dan penuh percaya diri; e) Siswa mendiskusikan dalam kelompok tentang hubungan atas berbagai informasi berkaitan dengan perumusan dan penetapan Pancasila yang diperolehnya dengan kerjasama dan penuh tanggung jawab; f) Siswa secara kelompok untuk menyimpulkan pembentukan BPUPKI dan mempresentasikannya baik secara tertulis maupun lisan dengan rasa percaya diri; g) Siswa mensimulasikan atau memamerkan hasil proses perumusan dan penetapan Pancasila sebagai dasar negara; h) Siswa menyusun laporan hasil telaah tentang pembentukan BPUPKI. Laporan dapat berupa display, bahan tayang, maupun dalam bentuk kertas lembaran. Manfaatkan sumber daya alam atau bahan bekas yang ada di lingkungan siswa untuk membuat bahan tayang; g) Guru memberikan konfirmasi terhadap jawaban siswa dalam diskusi, dengan meluruskan jawaban yang kurang tepat dan memberikan penghargaan bila jawaban benar dengan pujian atau tepuk tangan bersama.

Berdasarkan hasil wawancara diketahui juga bahwa penanaman nilai-nilai nasionalisme pada siswa di MTs Negeri 6 Aceh Besar dilaksanakan melalui berbagai kegiatan sekolah yang menggunakan pendekatan proses belajar peserta didik secara aktif dan berpusat pada anak antara lain penanaman nilai- nilai nasionalisme melalui pengintegrasian nilai-nilai nasionalisme ke dalam pembelajran, kegiatan-kegiatan terprogram, pembiasaan sekolah, dan kegiatan luar sekolah.

Penanaman nilai-nilai nasionalisme dilaksanakan melalui pengintegrasian nilai nasionalisme ke dalam pembelajaran. Penanaman nilai-nilai nasionalisme pada siswa di MTs Negeri 6 Aceh Besar diintegrasikan ke dalam beberapa mata pelajaran yang relevan dengan nilai-nilai nasionalisme diantaranya PKn, Bahasa Indonesia, Bahasa Inggris, Penjaskes, Sosiologi, Sejarah, dan Seni. Pengitegrasian nilai-nilai nasionalisme ke dalam mata pelajaran secara tepat dan baik maka tujuan pembelajaran dapat tercapai yaitu dengan tertanamnya nilai- nilai nasionalisme pada pribadi peserta didik. Pembelajaran yang dilakukan menggunakan pendekatan proses belajar peserta didik secara aktif dan berpusat pada anak agar dapat membentuk kecintaan pada bangsa dan negaranya. Hal ini sesuai dengan Hoskin, at all (2014), yang meneliti tentang "Civic Competence of Youth in Europe: Measuring Cross National Variation Through the Creation of a Composite Indicator (Kompetensi Kewarganegaraan Pemuda di Eropa: Mengukur Variasi Lintas Nasional Melalui Penciptaan Indikator Komposit). Hasil penelitian menjelaskan bahwa nilai keadilan sosial dan pengetahuan kewarganegaraan dan keterampilan siswa difasilitasi dalam sistem Nordik yang menggabungkan demokrasi dan kemakmuran ekonomi yang stabil dengan sistem pendidikan berbasis demokrasi di mana para guru memprioritaskan untuk mempromosikan pemikiran kritis otonom dalam pendidikan kewarganegaraan.Sebaliknya, demokrasi jangka menengah dengan tradisi republik sipil, seperti Italia dan Yunani mendapatkan hasil yang lebih positif mengenai nilai kewarganegaraan dan sikap partisipatif.Ini juga terjadi pada beberapa negara komunis barubaru ini yang mempertahankan gagasan etnik kewarganegaraan. Pada langkah terakhir, 
kami melanjutkan untuk memperdebatkan bahwa prioritas guru Nordik dalam mengembangkan warga negara yang kritis dan otonom mungkin memfasilitasi kualitas kognisi 14 tahun mengenai kewarganegaraan dan nilai kesetaraan tetapi mungkin bukan pendekatan yang paling bermanfaat untuk meningkatkan sikap atau konsep partisipatif. warga negara yang baik yang mungkin lebih didukung oleh prioritas guru bahasa Italia dalam tanggung jawab kewarganegaraan.

Setelah perangkat pembelajaran lengkap maka baru guru melaksanakan pembelajaran di kelas dengan metode, media, sumber/bahan ajar yang telah dirancang. Guru menggunakan sumber belajar/ media yang menarik seperti video, gambar, alat peraga, LCD, dan tape recorder sehingga pembelajaran dapat berlangsung secara aktif, menarik, menyenangkan serta tidak membuat jenuh dan bosan peserta didik. Ketika pembelajaran dimulai maka sikap dari peserta didik adalah tertib, menghargai guru yang sedang mengajar dengan memperhatikannya, aktif dalam pembelajaran yaitu bertanya, berpendapat dan berusaha mencari penyelesaian dari tugas yang diberikan guru secara mandiri, membantu teman yang belum paham atau kesusahan, serta mengikuti pembelajaran dengan semangat dan tanpa rasa jenuh atau bosan. Siswa antusias dalam mengikuti pembelajaran Sikap atau perilaku ini mereka lakukan setelah mendapatkan pendidikan nasionalisme yang dirancang oleh sekolah dalam hal ini adalah guru baik melalui pembelajaran. Guru melaksanakan apa yang telah direncanakannya sebelumnya dalam rencana pelaksanaan pembelajaran RPP yang merupakan penguraian dari silabus yang telah disisipkan dengan nilai-nilai nasionalisme. Rencana pelaksanaan pembelajaran (RPP) merupakan acuan guru dalam melaksanakan pembelajaran. Guru melaksanakan pembelajaran terkait penanaman nilai nasionalisme dengan menggunakan metode dan strategi yang berpusat kepada siswa sehingga menuntut siswa menjadi aktif dan menciptakan pembelajaran yang menyenagkan dan menantang. Guru melaksanakan pembelajaran denga menyisipkan nilai-nilai dan materi nasionalisme kedalam pembelajaran yang sarat akan pengembangan diri peserta didik ke arah yang positif.

Penanaman nilai nasionalisme kepada siswa di MTs Negeri 6 Aceh Besar bertujuan untuk menumbuhkan, memelihara dan mengembangkan kesadaran berbangsa dan bernegara Indonesia, kecintaan terhadap tanah air, keyakinan Pancasila sebagai ideologi, falsafah dan dasar negara, kerelaan berkorban untuk negara, serta kemampuan awal bela negara bagi seluruh warga MTs Negeri 6 Aceh Besar serta dapat menerapkan wawasan kebangsaan itu ke dalam kehidupan sehari-hari. Penanaman nilai-nilai nasionalisme juga dilaksanakan melalui kegiatan-kegiatan terprogram.Kegiatan terprogram merupakan kegiatan yang dalam pelaksanaannya terlebih dahulu diawali dengan adanya perencanaan atau program dari sekolah.Kegiatan terprogram tersebut direncanakan melalui program kerja yang disusun oleh sekolah.Kegiatan teprogram merupakan salah satu kegiatan pengembangan diri siswa.Kegiatan terprogram tersebut terdiri dari kegiatan-kegiatan seperti memperingati hari besar Nasional sebagai sebuah sarana penanaman nilai-nilai nasionalisme. Peringatan hari besar nasional ini bertujuan untuk mengenang dan menghormati apa yang telah terjadi pada hari-hari besar nasional tersebut serta kita dapat memetik makna yang terkandung dalam hari besar tersebut. MTs Negeri 6 Aceh Besar memperingati hari-hari dengan mengikuti upacara bendera serta mengadakan lombalomba sesuai dengan hari nasional yang diperingati sehingga harapkan dapat menjadi sarana penanaman nilai-nilai nasionalisme.

MTs Negeri 6 Aceh Besar juga memprogram kegiatan bakti sosial sebagai salah satu sarana penanaman nilai-nilai nasionalisme.Kegiatan bakti sosial merupakan sebuah bentuk kepedulian dan tanggung jawab sosial untuk dapat memberikan manfaat terhadap masyarakat.Kegiatan bakti sosial ini telah dilaksanakan oleh MTs Negeri 6 Aceh Besar yang melibatkan peserta didik secara langsung untuk terjun di lapangan dalam kegiatan ini. Berdasarkan hasil penelitian kegiatan bakti sosial MTs Negeri 6 Aceh Besar dilaksanakan 
melalui berbagai kegiatan diantaranya kerja bakti membersihkan dan merawat lingkungan di sekitar sekolah seperti (tempat ibadah, lingkungan desa, tempat- tempat wisata, pemakaman, dsb), mengumpulkan pakaian pantas pakai dan iuran untuk disumbangkan ke panti-panti asuhan dan orang-orang kurang mampu, membantu korban bencana alam dan sebagainya.

Kegiatatan ekstrakurikuler juga merupakan salah satu kegiatan terprogram dalam penanaman nilai-nilai nasionalisme.Kegiatan ekstrakurikuler adalah kegiatan pendidikan di luar mata pelajaran dan pelayanan konseling untuk membantu pengembangan peserta didik sesuai dengan kebutuhan, potensi, bakat, dan minat mereka melalui kegiatan yang secara khusus diselenggarakan oleh pendidik dan atau tenaga kependidikan yang berkemampuan dan berkewenangan di sekolah/madrasah.Hal ini sesuai dengan Kemendiknas Provinsi Jawa Tengah (2010: 5) bahwa pembinaan nasionalisme dan karakter bangsa melalui kegiatan ekstrakurikuler adalah suatu pengelolaan kegiatan secara sistematis, terencana dan terpadu terhadap peserta didik dengan mengacu pada nilai-nilai luhur Pancasila yang dilakukan oleh pemangku kepentingan pendidikan. Materi nasionalisme dan karakter bangsa yang akan diintegrasikan ke dalam kegiatan ekstrakurikuler mencakupi aspek kesadaran berbangsa dan bernegara, kecintaan terhadap tanah air, keyakinan terhadap Pancasila, kerelaan berkorban dan kesiapan awal bela negara. Implementasi materi tersebut akan diperkaya dengan nilai-nilai kecerdasan emosional, spiritual, sosial, kinestetik, serta khasanah budaya dan kearifan lokal. Berdasarkan hal tersebut, maka penerapan pengintegrasian materi nasionalisme dan karakter bangsa melalui kegiatan ekstrakurikuler menuntut kreativitas para pembina kesiswaan di satuan pendidikan. Hal ini sesuai dengan Kemendiknas Provinsi Jawa Tengah (2010: 8) Materi pembinaan nasionalisme dan karakter bangsa melalui kegiatan ekstrakurikuler meliputi: (a) pembinaan keimanan dan ketakwaan terhadap Tuhan Yang Maha Esa; (b) pembinaan budi pekerti dan akhlak mulia; (c) pembinaan kepribadian unggul, wawasan kebangsaan dan belanegara; (d) pembinaan prestasi akademik, seni, olahraga sesuai dengan bakat dan minatnya; (e) pembinaan demokrasi, hak asasi manusia, pendidikan politik, lingkungan hidup,kepekaan dan toleransi sosial dalam konteks masyarakat plural; (f) pembinaan kreativitas, keterampilan dan kewirausahaan; (g) pembinaan kualitas jasmani, kesehatan, gizi yang terdiversifikasi; (h) pembinaan sastra budaya; (i) pembinaan teknologi informasi dan komunikasi; dan (j) pembinaan komunikasi dalam berbahasa.

Melalui kegiatan ekstrakurikuler ini MTs Negeri 6 Aceh Besar berupaya untuk melaksanakan penanaman nilai-nilai nasionalisme dengan cara mengintegrasikan nilai-nilai nasionalisme ke dalam kegiatan ekstrakurikuker. Berdasarkan hasil penelitian di lapangan menunjukkan bahwa penanaman nilai- nilai nasionalisme melalui kegiatan ekstrakurikuler dapat dilaksanakan dalam kegiatan ekstrakurikuler yang ada di MTs Negeri 6 Aceh Besar .Kegiatan ekstarkurikuler dilaksanakan sesuai dengan jadwal yang telah ditentukan. Biasanya kegiatan ekstrakurikuler dilaksanakan diluar jam pelajaran, sesudah pulang sekolah. Kegiatan ekstrakurikuler dapat mengembangkan bakat yang dimiliki peserta didik. Penanaman nilai-nasionalisme nasionalisme di MTs Negeri 6 Aceh Besar melalui ekstrakurikuler lebih difokusfkan terhadap ekstrakurikuler yang dianggap relevan seperti: Pramuka, pasukan pengibar bendera, palang merah remaja (PMR) tetapi juga tidak terlepas dari ekstrakurikuler lain seperti: basket, karate, Voly, sepak bola, bahasa inggris, komputer dan sebagainya. Hal ini sesuai dengan Kemendiknas Provinsi Jawa 
Tengah (2010: 12) strategi pembinaan nasionalisme dan karakter bangsa melalui kegiatan ekstrakurikuler dilaksanakan dengan menyelenggarakan kegiatan- kegiatan ekstrakurikuler yang telah ada seperti kepramukaan, Palang Merah Remaja, Pasukan Pengibar Bendera (Paskibra), maupun mengembangkan kegiatan ekstrakurikuler alternatif seperti teater, musik, tari, teknologi dan sebagainya sesuai dengan kebutuhan, bakat/minat peserta didik serta disesuaikan dengan kemampuan satuan pendidikan.

MTs Negeri 6 Aceh Besar juga memprogram kegiatan menghias kelas dengan tema nasionalisme yang bertujuan untuk menanamakan nilai-nilai nasionalisme kepada siswa serta mengasah kreativitas siswa.Berdasarkan hasil penelitian setiap kelas telah di hiasi dengan tema nasionalisme.Setiap kelas dihias oleh siswa dengan tema nasionalisme sesuai dengan kreatifitas siswa kelas tersebut. Hampir setiap kelas dipasangi atribut-atribur nasional seperti: pemasangan bendera di setiap kelas, pemasangan symbol Lambang Negara, Garuda, gambar Presiden dan Wakil Presiden, pemasangan peta atlas, pemasangan gambar-gambar pahlawan.

Penanaman nilai-nilai nasionalisme di MTs Negeri 6 Aceh Besar juga dilaksanakan melalui kegiatan pembiasaan.Pembiasaan merupakan sesuatu yang sengaja dilakukan secara berulang-ulang agar sesuatu itu dapat menjadi kebiasaan. Dalam proses pembelajaran di sekolah, kebiasaan dijadikan sebagai pendekatan pembiasaan. Hal ini sesuai dengan pendapat Djamarah \& Zain (2009: 71) bahwa pendidikan adalah alat pendidikan. Pembiasaan yang baik di sekolah akan membentuk anak menjadi berkepribadian baik.

Tujuan pembiasaan secara umum menurut Undang-Undang Republik Indonesia No.20 tahun 2003 yaitu untuk mengembangkan potensi siswa agar menjadi manusia yang beriman dan bertakwa kepada Tuhan Yang Maha Esa, berakhlak mulia, sehat, berilmu, cakap, kreatif, mandiri, dan menjadi warga negara yang demokratis serta bertanggungjawab. Pendekatan yang dilakukan dalam pelaksanaan pendidikan nasionalisme melalui pembiasaan dapat dilakukan melalui kegiatan rutin, kegiatan spontan, kegiatan pemberian keteladanan dan kegiatan terprogram. Pelaksanaan program pembiasaan di sekolah dapat dilakukan melalui bebarapa pendekatan antara lain kegiatan rutin, kegiatan spontan, kegiatan teladan, dan kegiatan terprogram. Kegiatan rutin yang dilakukan dengan menanamkan nilai-nilai nasionalisme kepada siswa secara rutin. Adapun bentuk kegiatan rutin yang dilakukan pelaksanaan pendidikan nasionalisme melalui pembiasaan antara lain upacara bendera yang dilaksanakan setiap hari Senin dan hari-hari besar nasional, jadwal piket harian, memperdengarkan lagu-lagu kebangsaaan sebelum pembelajaran, pengibaran bendera di depan sekolahan oleh siswa setiap hari, berdo'a pada awal dan akhir pembelajaran.

Penanaman nilai-nilai nasionalisme kepada peserta didik melalui pembiasaan dilaksanakan dengan nilai-nilai nasionalisme yang berbeda dalam setiap kegiatan sesuai dengan kegiatan pembiasaan yang akan dilaksanakan. Misalnya pada saat upacara bendera yang dilaksanakan setiap hari Senin itu, nilai-nilai yang terkandung dalam pelaksanaan upacara bendera diantaranya membiasakan siswa untuk bersikap tertib dan disiplin, membiasakan siswa berpenampilan rapi, meningkatkan kemampuan mempimpin, membuat siswa patuh pada aturan yang ada, dan menanamkan rasa tanggungjawab. Sehingga diharapkan dengan adanya kegiatan rutin yang dilakukan di sekolah diharapkan kian mempertebal semangat kebangsaan, cinta tanah air, patriotisme, semangat dan nilai-nilai kepahlawanan, idealisme serta membangkitkan peran siswa dalam kehidupan berbangsa dan bernegara. Hal ini sesuai dengan Tataran Dasar Bela Negara (2010: 3) bahwa kesadaran berbangsa berarti sikap dan tingkah laku yang harus sesuai dengan kepribadian bangsa, dan selalu mengaitkan dirinya dengan cita-cita dan tujuan hidup bangsanya yaitu dengan 
menumbuhkan rasa kesatuan dan persatuan bangsa dan negara Indonesia, menumbuhkan rasa memiliki jiwa besar dan patriotisme, dan memiliki kesadaran atas tanggungjawab sebagai warga negara Indonesia.

Kegiatan pemberian teladan kepada siswa yang dilakukan oleh guru MTs Negeri 6 Aceh Besar dilaksanakan dengan memberikan contoh sikap, tutur kata dan perilaku yang baik sehingga dapat menjadi panutan yang baik bagi siswa.Pendidik berusaha untuk memberikan teladan yang baik kepada para peserta didiknya. Keteladanan merupakan kegiatan yang dilakukan dengan memberikan contoh tentang pembelajaran pembiasaan yang baik, sehingga diharapkan akan menjadi panutan bagi para siswa. Keteladanan para pendidik mempunyai kontribusi yang besar dalam menanamkan nilai-nilai nasionalisme.Segala sikap dan tingkah laku pendidik baik di sekolah, di rumah maupun di masyarakat hendaknya selalu menunjukkan sikap dan tingkah laku yang baik. Hal tersebut dapat dilihat ketika guru selalu mengucap salam dan berjabat tangan jika bertemu dengan guru yang lain, selalu berpakain rapi, berusaha untuk datang tepat waktu, tidak membuang sampah di sembarang tempat, dan bertutur kata dengan sopan. Dari contoh tersebut, maka siswa akan melaksanakan perbuatan seperti yang dicontohkan oleh guru. Hal ini dilakukan agar siswa mengikuti apa yang dilakukan gurunya. Siswa akan meniru dan jika dilakukan secara terus menerus maka hal ini akan menjadi suatu kebiasaan.

Kegiatan pembiasaan yang dilakukan di MTs Negeri 6 Aceh Besar seperti upacara Bendera, memperdengarkan lagu-lagu Kebangsaan, mengibarkan Bendera di halaman depan sekolah oleh siswa setiap hari, membudayakan 3S (Senyum, Sapa, Salam), piket kelas, doa awal pelajaran dan akhir pelajaran, pemakaian Pin Abita sangat menunjang dalam menanamkan nilai-nilai nasionalisme kepada siswa. Kegiatan ini juga mengajarkan kepada anak untuk dapat bekerjasama dengan teman, saling tolong menolong, dan menghargai orang lain. Nilai-nilai yang ditanamkan dalam kegiatan pembiasaan di MTs Negeri 6 Aceh Besar antara lain nilai cinta tanah air, rela berkorban, berani, mandiri, tanggungjawab, peduli lingkungan, kerja sama, semangat kebangsaan, ketuhanan, dan kreatifitas. Dalam pelaksanaannya, anak dilibatkan secara langsung dalam penanaman dan pengembangan nilai-nilai tersebut serta mempraktekannya secara langsung dalam kehidupan sehari-hari.

Berdasarkan hasil penelitian nilai-nilai yang ditanamkan dalam penanaman nilanilai nasionalisme pada siswa di MTs Negeri 6 Aceh Besar adalah nilai religius, jujur, toleransi, disiplin, kerja keras, kreatif, mandiri, demokratis, rasa ingin tahu, semangat kebangsaan, cinta tanah air, menghargai prestasi, bersahabat/komunikatif, cinta damai, gemar membaca, peduli lingkungan, peduli sosial, tanggung jawab akan tetapi yang diutamakan adalah nilai religiuas, toleransi, disiplin, cinta tanah air, menghargai prestasi dan peduli sosial.

Sebagaimana penelitian yang dilakukan oleh Leung, Y.W (2014).Penelitian tentang "Nasionalistic Education and Indostrination", Studi kasus yang berfokus pada pemahaman dan praktik pendidikan nasionalistik terhadap tiga pendidik masyarakat yang pemahamannya mengarah padapendidikan untuk nasionalisme totaliter di sekolah menengah Hong Kong, dengan menggunakan konsep indoktrinasi.Temuan menunjukkan bahwa karena ketidakmampuan para guru memisahkan bangsa dari partai yang berkuasa dan misi kuat mereka untuk mengirimkan citra positif partai kepada murid mereka, mereka cenderung menerapkan strategi pengajaran tertentu, yang dapat menekan kemampuan siswa.Untuk mencerminkan secara kritis, menurut kriteria indoktrinasi, yaitu hubungan, niat, isi dan metode pengajaran, pendekatan pengajaran mereka cenderung bersifat indoktrinasi, bukan pendidikan.Hal ini tentu saja tidak dapat diterima oleh mereka yang percaya bahwa pendidikan berkaitan dengan pengembangan individu yang berpikiran independen dan kritis. 
3. Pelaksanaan penanaman nilai-nilai nasionalisme pada kegiatan penutup dalam pembelajaran PKn di MTs Negeri 6 Aceh Besar

Pelaksanaan penanaman nilai-nilai nasionalisme pada kegiatan penutup dalam pembelajaran PKn di MTs Negeri 6 Aceh Besar dimaksudkan untuk menilai kualitas proses penanaman nilai-nilai nasionalisme dan pembentukan kompetensi peserta didik dalam penanaman nilai-nilai nasionalisme. Pelaksanaan penanaman nilai-nilai nasionalisme pada kegiatan penutup dalam pembelajaran PKn di MTs Negeri Ngemplak dapat berupa: a) Guru memberikan umpan balik atas proses uji Kompetensi 1.1 atau soal yang disusun guru sesuai pembelajaran dan hasil telaah kelompok; b) Guru memberikan tes tertulis dengan menggunakan indikator pencapaian kompetensi; dan c) Guru menjelaskan rencana pembelajaran selanjutnya dan menugaskan peserta dididk membaca materi pertemuan berikutnya, yaitu perumusan Dasar Negara.

Penilaian pendidikan nasionalisme dititikberatkan kepada keberhasilan penerapan nilai-nilai dalam sikap dan perilaku peserta didik sesuai dengan nilai- nilai nasionalisme yang diterapkan dan diamalkan dalam kehidupan dikelas dan lingkungan sekolah untuk membentuk nilai-nilai sosial di masayrakat.Hal ini sebagaimana penelitian yang dilakukan oleh Setyowati, (2012), yang meneliti tentang Nasionalism Applying in Learning Civic Education as Moral Learning Media ini University, jenis penelitian kepustakaan, data sekunder dikumpulkan dengan mengidentifikasi dokumen, buku, dan jurnal yang relevan. Hasil ulasannya dapat disimpulkan bahwa pendidikan kewarganegaraan di universitas diwajibkan untuk memperkuat siswa dalam membentuk sikap nasionalisme. Siswa mempelopori masa depan sebuah negara yang harus mereka cintai negara mereka karena ilmu yang diterima harus diterapkan dalam kehidupan sosial mereka.

Penilaian dengan pengamatan/ observasi melalui skala sikap dilaksanakan setiap saat oleh guru pada setiap kesempatan baik ketika di dalam kelas maupun kegiatan sekolah lainnya di luar kelas dan pada setiap akhir semester. Hal ini sesuai dengan penelitian yang dilakukan oleh Indriyani (2014), bahwa: Pemahaman nilai-nilai nasionalisme pada siswa kelas VII sudah baik, terlihat dari siswa dalam mengikuti proses pembelajaran di kelas maupun di luar kelas sudah senantiasa mengamalkan nilai-nilai nasionalisme, Usaha penanaman nilai-nilai nasionalisme yang dilakukan guru melalui proses pembelajaran Pendidikan Kewarganegaraan pada siswa kelas VII yaitu guru selalu mengecek kelengkapan buku paket dan tugas siswa sebelum memulai pembelajaran, guru selalu memberi kesempatan siswa untuk bertanya, dan guru memotivasi siswa untuk meningkatkan rasa persatuan dan kesatuan serta mencintai kebudayaan / produk asli dalam negeri, 3) Partisipasi dalam penanaman nilai-nilai nasionalisme melalui proses pembelajaran Pendidikan Kewarganegaraan pada siswa kelas VII yaitu, siswa berperan aktif dalam proses pembelajaran di kelas maupun di luar kelas dengan ikut berpartisipasi dalam kegiatan upacara dan pramuka, 4) Pelaksanaan penanaman nilai-nilai nasionalisme melalui proses pembelajaran Pendidikan Kewarganegaraan pada siswa kelas yaitu, tercermin pada keinginan menjadi warga negara yang baik, setia terhadap negara, menghormati negara dalam keadaan apapun, dan senantiasa mencintai negara. Nilai-nilai nasionalisme tersebut diimplementasikan dalam proses pembelajaran di kelas, interaksi siswa dengan siswa dan siswa dengan guru baik di dalam maupun di luar kelas.

Penilaian terkait dengan penanaman nilai-nilai nasionalisme tidak hanya dilakukan oleh guru terhapap siswa, akan tetapi penilaian ini juga dilakukan oleh kepala sekolah terhadap proses pelaksanaan penanaman nilai-nilai yang dilakukan oleh guru terkait. Penilaian ini bertujuan untuk supervisi guna mengevaluasi jalannya penanaman nilai-nilai nasionalisme di MTs Negeri Ngemplak. Berdasarkan hasil dokumentasi kepala sekolah melakukan penilaian dengan cara observasi terhadap pembelajaran yang dilakukan oleh guru di kelas. Penilaian dilakukan dengan menggunakan lembar pengamatan pembelajaran oleh kepala sekolah.Di dalam lembar pengamatan pembelajaran tersebut kepala sekolah 
mengobservasi dari perencanaan, pelaksanaan sampai dengan penilaian yang dilakukan oleh guru terkait.Kepala sekolah dalam menilai mencatat fakta- fakta yang terjadi selama observasi pembelajaran ini. Catatan ini selanjutnya akan digunakan untuk bahan acuan diskusi dengan guru terkait dengan penanaman nilai-nilai nasionalisme. Penanaman nilai-nilai nasionalisme di MTs Negeri 6 Aceh Besar dinilai telah berhasil dengan baik dijalankan hal ini terlihat dari perubahan sikap dan perilaku siswa serta terlihat dari keberhasilan sekolah.

\section{SIMPULAN}

Penanaman nilai-nilai nasionalisme melalui pembelajaran Pendidikan Kewarganegara pada siswa di MTs Negeri 6 Aceh Besar Tahun 2012, dapat disimpulkan sebagaimana uraian berikut:

1. Penanaman nilai-nilai nasionalisme pada kegiatan pendahuluan dalam pembelajaran PKn di MTs Negeri 6 Aceh Besar, yaitu: a) Guru mengkondisikan dan mempersiapkan suasana belajar yang menyenangkan melalui pemberian salam dan sapa kepada siswa dilanjutkan memperhatikan kesiapan fisik dan psikis untuk mengikuti pembelajaran dengan melakukan doa, menanyakan kehadiran siswa, kebersihan dan kerapian, b) Guru menyampaikan kompetensi dasar dan indikator pencapaian kompetensi yang akan dicapai dan c) Guru menjelaskan materi dan kegiatan pembelajaran yang akan dilakukan siswa.

2. Penanaman nilai-nilai nasionalisme pada kegiatan inti dalam pembelajaran PKn di MTs Negeri 6 Aceh Besar yaitu: a) Kegiatan eksplorasi yaitu guru menggunakan beragham pendekatan pembelajaran, media dan sumber belajar lain dan melibatkan peserta didik secara aktuf dalam setiap kegiatan pembealajran; b) Kegiatan elaborasi: guru memfasilitasi peserta didik melakukan kegiatan yang menumbuhkan kebanggan dan rasa percaya diri dengan menguraijkan nilai-nilai Pancasila; c) Konfirmasi : guru memberikan umpan balik positif dan penguatan serta bertanya jawab tentang hal yang belum diketahui siswa dan guru beserta siswa bertanya jawab meluruskan kesalahan pemahaman, memberikan penguatan dan penyimpulan.

3. Penanaman nilai-nilai nasionalisme pada kegiatan penutup dalam pembelajaran PKn di MTs Negeri 6 Aceh Besar yaitu: Guru beserta siswa membuat rangkuman/simpulan pelajaran, melakukan penilaian atau refleksi terhadap kegiatan yang sudah dilaksaakan secara konsisten dan terprogram, memberikan umpan balik terhadap proses dan hasil pembelajaran dan menyampaikan rencana pembelajaran pada pertemuan berikutnya.

\section{DAFTAR PUSTAKA}

Christopher, D.H. 2012. Internationalization, nationalism, and global competitiveness: a comparison of approaches to higher education in China and Japan.

Hoskin B, Saisana M, Villalba C.M.H. 2014. Civic Competence of Youth in Europe: Measuring Cross National Variation Through the Creation of a Composite Indicator. This article is published with open access at Springerlink.com

Indriyani, S. 2014. Penanaman Nilai-nilai Nasionalisme melalui pembelajaran pendidikan kewarganegaraan (Studi kasus di MTs Negeri Surakarta II tahun 2013). Naskah Publikasi Ilmiah. Surakarta: Surakarta: UMS, MAP PPS.

Isnawati, N. 2010. Guru Positif-Inovatif. Yogyakarta: Laksana

Kemendiknas Provinsi Jawa Tengah. 2010. Pedoman Umum Pembinaan Nasionalisme Melalui Jalur Pendidikan. Kemendiknas Provinsi Jawa Tengah

Kemendiknas Provinsi Jawa Tengah. 2010. Pedoman Umum Pembinaan Nasionalisme dan Karakter Bangsa Melalui Jalur Ekstrakurikuler.Kemendiknas Provinsi Jawa Tengah

Kementrian Pertahanan RI Direktorat Jendral Potensi Pertahanan. 2010. Tataran Dasar Bela Negara. Jakarta: Kementrian Pertahanan RI Direktorat Jendral Potensi Pertahanan. 
Lambert. E.K., Ibe. D, Nwanne. 2014. Performance Appraisal and Labour Relations Practices as Correlates of Teachers' Professional Commitment in Public Secondary Schools in Abia State, Nigeria. Journal of Education and Practice.Vol.5, No.32, 2014.

Leung, Y.W. 2014.Nasionalistic Education and Indostrination.Citizenship, Social and Economics Education.Vol. 2.No. 2. 2014. Hong Kong Institute of Education, Taipo, Hong Kong SAR, People's Republic of China.

Nurdin, E.S. 2015.The Policies on Civic Education in Developing Nationalism Character in Indonesia.International Education Studies; Vol. 8, No. 8; 2015. ISSN 1913-9020 EISSN 1913-9039. Published by Canadian Center of Science and Education.

Rewantina.2013. Penanaman Nilai Nasionalisme dan Patriotisme untuk Mewujudkan Pendidikan Karakter pada Mata Pelajaran Pendidikan Kewargenagaraan Siswa Kelas X SMA Negeri 4 Sidoharjo.Jurnal Publikasi Ilmiah. Surakarta: UMS, MAP PPS.

Setyowati, R. 2012. Nasionalism Applying in Learning Civic Education as Moral Learning Media ini University. Journal of Education, Teaching and Learning Volume 1 Number 1 March 2012. Page 22-25 p-ISSN: 2477-5924 e-ISSN: 2477-4878.

UU No. 20 tahun 2003.2009. Sistem Pendidikan Nasional.Yogyakarta: Pustaka Pelajar.

Volkeh, B. 2014.Nationalism - Ethnicity - Racism?Thinking History in a World of Nations.Review of History and Political Science. March 2014, Vol. 2, No. 1, pp. 2950. Published by American Research Institute for Policy Development. Wahjosumidjo. 2010. Kepemimpinan Kepala Sekolah. Jakarta: Rajawali Grafindo Persada.

Wuryandani, W. 2013. Membangun Karakter Bangsa Melalui Penanaman Nilai Nasionalisme. Jurnal Pendidikan. Pendidikan Pra Sekolah dan Sekolah Dasar Fakultas Ilmu Pendidikan Universitas Negeri Yogyakarta.Jurnal Pendidikan. Jurusan PPSD, Yogyakarta: UNY. 